\title{
A case of $\gamma 3$ heavy chain disease with vacuolated plasma cells: a clinical, immunological, and ultrastructural study
}

\author{
WALTER FEREMANS ${ }^{1}$, MICHEL CAUDRON ${ }^{2}$, AND CLAUDE BIEVA ${ }^{3}$ \\ From the ${ }^{1}$ Department of Medicine, St Pierre Hospital, Department of Medicine, IMC Anderlecht, \\ Laboratory of Pathology and Electron Microscopy, Université Libre de Bruxelles, Belgium; \\ ${ }^{2}$ Department of Haematology, St Pierre Hospital, MAB Laboratory, Mons, Belgium; and \\ ${ }^{3}$ Department of Immunology, St Pierre Hospital, Université Libre de Bruxelles, Belgium
}

SUMMARY A patient with lambda Bence-Jones proteinuria, Waldenström's macroglobulinaemia, and Franklin's disease ( $\gamma$ HCD), but without clinical evidence of a lymphoproliferative disorder, is presented. The serum contained two distinct immunoglobulin abnormalities: a monoclonal immunoglobulin $\mathbf{M}$ (IgM) of lambda type, and a protein fragment which was immunologically related to immunoglobulin G (IgG) and devoid of light chain activity. This $\gamma$ HCD protein belongs to the $\gamma 3$ subclass with a molecular weight of approximately 60000 daltons. The urine contained a BenceJones lambda protein as well as the $\gamma$ HCD fragment. The two paraproteins were probably secreted by two different malignant clones. Ultrastructural study revealed pathological vacuolated plasma cells of a sort that has hitherto been principally described in association with $\mu$ HCD. The mechanism of the intracellular storage of pathological immunoglobulins is discussed in the light of the ultrastructural study.

The plasma cell dyscrasias, multiple myeloma and macroglobulinaemia, and the association between them have been the subject of intensive investigations in recent years.

The diagnosis of gamma heavy chain disease ( $\gamma$ HCD), described by Franklin et al. in 1964, requires the identification in serum and urine of homogeneous populations of incomplete heavy chains of the IgG immunoglobulin class. Up to 1973 , more than 30 cases of $\gamma$ HCD had been identified (Frangione and Franklin, 1973).

The $\gamma$ HCD has a well-defined clinical and pathological picture. Generalised lymphadenopathy, enlargement of the liver and spleen, oedema of the soft palate and uvula, pleural effusion, and ascites have been described (Osserman and Takatsuki, 1964; Delmas-Marsalet et al., 1971; Seligmann, 1972; Bloch et al., 1973). The importance of the presence of atypical forms of plasma cells and lymphocytes is reported by most authors (Zucker-Franklin, 1964; Fisher and Zawadzki, 1970; Hobbs, 1971; Lennert et al., 1975), and ultrastructural study has revealed abnormalities associated with the intracellular storage of pathological immunoglobulins (Feremans et al., 1978).

Received for publication 13 September 1978
Progress has also been made in defining the molecular mechanism of some special associations of paraproteins such as $\mu$ chains with IgG gammopathy (Josephson et al., 1975), $\gamma 3$ chains with IgG $3 \lambda$ myeloma, as recently described by Adlersberg et al. (1978), or $\gamma 1$ heavy chain with IgG $\lambda$ and free $\lambda$ chains (Isobe and Osserman, 1974).

In this paper we describe an additional variant: a patient presenting the characteristics of BenceJones proteinuria, Waldenström's macroglobulinaemia, and $\gamma$ HCD but without clinical signs of lymphoma or myeloma.

\section{Material and methods}

\section{CASE REPORT}

An 87-year-old white woman was admitted to St Pierre Hospital, Brussels, in September 1976 suffering from anaemia and lung congestion with heart failure. Before admission the patient had been in good health.

\section{Physical examination}

Physical findings on admission included a pulse rate of $140 / \mathrm{min}$ and a blood pressure of $190 / 110 \mathrm{mmHg}$ and the patient appeared to have lost weight. There was bilateral lung congestion. She had no fever, no 
lymphadenopathy, no hepatosplenomegaly, and no palatal oedema.

\section{Laboratory data}

ESR $132 \mathrm{~mm} / \mathrm{h}$, haemoglobin $8.6 \mathrm{~g} / \mathrm{dl}$, RBC $2.7 \times$ $10^{12} / 1$, haematocrit $29.7 \%$, reticulocyte count $1.5 \%$, MCV $96 \mathrm{fl}$, MCHC $31.2 \mathrm{~g} / \mathrm{dl}$, MCH $30 \mathrm{pg}$, WBC $8.6 \times 10^{9} / 1$ with $51 \%$ lymphocytes, $47 \%$ neutrophils, $2 \%$ eosinophils, $2 \%$ monocytes, platelet count $364 \times 10^{9} / \mathrm{l}$, iron $16 \mu \mathrm{mol} / \mathrm{l}(89 \mu \mathrm{g} / 100 \mathrm{ml})$, IBC $52 \mu \mathrm{mol} / 1(288 \mu \mathrm{g} / 100 \mathrm{ml})$, haptoglobin $1.2 \mathrm{~g} / \mathrm{l}$ $(120 \mathrm{mg} / 100 \mathrm{ml})$. Bone marrow aspiration showed $19 \%$ dysplastic plasma cells (nucleocytoplasmic asynchronism and some cells resembling reticulum cells) and $22 \%$ lymphocytes, with a normal cellularity. Serum glutamic oxaloacetic transaminase and glutamic pyruvic transaminase gave, respectively, 21 and 14 Karmen units (normal value 22), lactic dehydrogenase 171 Berger-Broida units (normal 200), gamma glutamyl transferase 78 IU (normal 28), creatinine phosphokinase 17 IU (normal 50), alkaline phosphatase $216 \mathrm{IU}$ (normal 110), bilirubin $9 \mu \mathrm{mol} / 1(0.5 \mathrm{mg} / 100 \mathrm{ml})$, cholesterol $4.3 \mathrm{mmol} / \mathrm{l}$ $(167 \mathrm{mg} / 100 \mathrm{ml})$, triglycerides $1.1 \mathrm{mmol} / 1(98 \mathrm{mg} /$ $100 \mathrm{ml})$, urea nitrogen $88 \mathrm{mmol} / 1(123 \mathrm{mg} / 100 \mathrm{ml})$, creatinine $230 \mu \mathrm{mol} / 1(2 \cdot 6 \mathrm{mg} / 100 \mathrm{ml})$, calcium $2 \cdot 1$ $\mu \mathrm{mol} / 1 \quad(8.4 \mathrm{mg} / 100 \mathrm{ml})$, phosphate $1.6 \mathrm{mmol} / 1$ $(5 \mathrm{mg} / 100 \mathrm{ml})$, uric acid $8 \cdot 8 \mathrm{mg} / 100 \mathrm{ml}$, sodium 130 $\mathrm{mmol} / \mathrm{l}$, potassium $4.4 \mathrm{mmol} / \mathrm{l}$, chloride $97 \mathrm{mmol} / \mathrm{l}$, and carbon dioxide $2.7 \mathrm{kPa}(20 \mathrm{mmHg})$.

Chest $\mathrm{x}$-rays revealed cardiomegaly and vascular lung engorgement but no mediastinal lymphadenopathy. Liver-spleen scanning showed no hepatosplenomegaly; on an electrocardiogram there was sinus tachycardia with left bundle-branch block without myocardial infarction. We found small kidneys with a delay of bilateral elimination after intravenous pyelography.

\section{Immunological data (Table)}

The total serum protein was $80 \mathrm{~g} / \mathrm{l}(8 \mathrm{~g} / 100 \mathrm{ml})$. Microzone electrophoresis of serum and urine revealed migrating paraproteins which were further

\section{Table Immunological data}

\begin{tabular}{lc}
\hline Serum protein electrophoresis & $80 \mathrm{~g} / \mathrm{l}$ \\
albumin & $43 \%$ \\
$\alpha_{1}$-globulin & $2 \cdot 2 \%$ \\
$a_{2}$-globulin & $7 \cdot 7 \%$ \\
$\beta$-globulin & $7 \% \%$ \\
inter $\beta-\gamma$ peak & $27.8 \%$ \\
$\gamma$-globulin & $12.3 \%$ \\
Immunoelectrophoresis: \\
heavy chain disease of $\gamma \mathrm{G} 3$ specificity \\
proteinuria with $\lambda$ light chains \\
IgM lambda monoclonal component \\
\hline
\end{tabular}

characterised by immunoelectrophoresis. Cryoglobulin, LE cells, antinuclear factor, rheumatoid factor, and VDRL tests were negative. Direct Coombs' test was weakly positive for IgG. Proteinuria was $0.2 \mathrm{~g} / \mathrm{l}$. Quantitative examination of serum immunoglobulins gave the following results: IgG $60 \mathrm{~g} / \mathrm{l}(6000 \mathrm{mg} / 100 \mathrm{ml}), \mathrm{IgM} 13 \cdot 5 \mathrm{~g} / \mathrm{l}(1350 \mathrm{mg} / 100$ $\mathrm{ml})$ and $\operatorname{IgA} 2 \cdot 5 \mathrm{~g} / \mathrm{l}(250 \mathrm{mg} / 100 \mathrm{ml})$.

The distribution of chain specific surface immunoglobulins was $\gamma 10 \%$ (normal $2-5 \%$ ), $\alpha 0.4 \%$ (normal $0-4 \%$ ), and $\mu 6 \%$ (normal $5-10 \%$ ). The $\mathrm{K}: \lambda$ ratio was $1: 1$.

\section{Treatment and course}

Lung congestion was successfully treated with diuretics and digoxin. Anaemia was corrected by red cell transfusion. In July 1977 (10 months after diagnosis) the patient died of pneumonia. Postmortem examination was refused.

\section{METHODS FOR PROTEIN STUDIES}

Microzone electrophoresis of the patient's serum and concentrated urine was performed on cellulose acetate strips in a pH 8.6 veronal buffer. Immunoelectrophoresis was done according to Grabar and Williams (1953) and Osserman and Lawlor (1961), using polyvalent antisera against whole serum and specific antisera to heavy and light chains from different companies (Kallestad Lab, Chaska, Minn, USA; Behring Diagnostic Marburg, RFA; Dakopatts, Copenhagen, Denmark; Netherlands Red Cross Blood Transfusion Service, Amsterdam, Holland). Agarose gel electrophoresis was performed according to Johansson (1972) and immunofixation according to Ritchie and Smith (1976). Serum concentrations of immunoglobulins were measured by radial immunodiffusion (Mancini et al., 1965) using antibody-containing agar plates purchased from Kallestad Lab, Chaska, Minn, USA. Molecular weight was determined by dodecyl sulphate acrylamide gel electrophoresis using protein markers of known size obtained from Boehringer, Mannheim, RFA, according to Weber and Osborn (1969) and by Sephadex gel filtration on calibrated columns (Andrews, 1965). The identification of $\gamma$ heavy chain as belonging to subclass 3 was performed according to the directions for use of anti-human IgG subclass antisera by the Mancini technique (Central Laboratory of the Netherlands Red Cross Blood Transfusion Service).

METHODS FOR CELLULAR STUDIES

Light microscopy

Bone marrow smears were routinely stained by the May-Grünwald Giemsa method. 
Fluorescent microscopy (Pearse, 1960)

Smears were fixed for 5 minutes in absolute ethanol and rinsed in $0.15 \mathrm{M} \mathrm{pH} \mathrm{7.4}$ phosphate buffer at room temperature. Dako rabbit antihuman fluorescein conjugated antibodies, for IgA, IgM, IgG specific for $\mathrm{Fc}$ fragment, $\mathrm{K}, \lambda$, were used at the dilution of $1 / 40$ at $37^{\circ} \mathrm{C}$.

\section{Electron microscopy}

Bone marrow obtained by sternal puncture was immediately fixed for $\mathbf{3 0}$ minutes at room temperature in $4 \%$ distilled glutaraldehyde in $0.1 \mathrm{M}$ phosphate buffer.

The cells were rinsed in the same buffer and postfixed with $2 \%$ osmium tetroxide (Millonig, 1962). Dehydration took place in graded concentrations of ethanol with centrifugation for 10 minutes at 1000 rpm at each step of the manipulation.

Finally, the material was embedded in Epon (Luft, 1961) and sectioned with a Diatome diamond knife on an LKB Ultratome III microtome. Ultrathin sections were stained with uranyl acetate and lead and observed with a Siemens Elmiskop I electron microscope.

\section{Results}

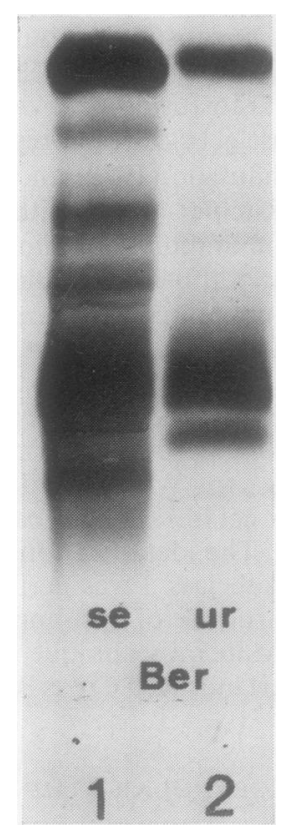

Fig. 1 Agarose gel electrophoresis of the patient's serum (se) and $\times 100$ concentrated urine (ur). The $M$-components are clearly visible in the $\beta-\gamma$ region.

\section{PROTEIN STUDIES}

Microzone electrophoresis revealed a broad peak of $\beta-\gamma$ mobility for serum and concentrated urine. Agarose gel electrophoresis showed a second peak in serum and urine (Fig. 1). Quantitative serum immunoglobulin analyses gave values of about $60 \mathrm{~g} / 1(6000 \mathrm{mg} / 100 \mathrm{ml})$ for $\mathrm{IgG}, 13.5 \mathrm{~g} / 1(1350 \mathrm{mg} /$ $100 \mathrm{ml})$ for $I g M$, and $2.5 \mathrm{~g} / 1(250 \mathrm{mg} / 100 \mathrm{ml})$ for IgA. Immunoelectrophoretic patterns at various dilutions of the patient's serum demonstrated the presence of an abnormally slow migrating arc in the $\beta-\gamma$ region (Fig. 2).

The slow migrating protein band reacted with whole IgG and Fc fragment antisera but not with anti-k or anti- $\lambda$ sera nor with antisera specific for $\alpha$ chain, $\mu$ chain, and Fab fragment (Fig. 3). The molecular weight of the Fc fragment was estimated to be about 60000 daltons.

In additon, a second band reacted with $\mu$ and $\lambda$ chain specific antisera, as seen by immunofixation in Figure 4. Immunoelectrophoresis performed on a 100-fold concentrated urine sample showed the slow migrating fragment reacting identically with that in the serum. A second distinct band reacted only with free $\lambda$ light chain antisera (Fig. 5). No precipitation arc was detected between Fab specific antiserum and the concentrated urine sample.

\section{CELLULAR STUDIES}

The reaction with anti-IgM and anti- $\lambda$ fluorescein-

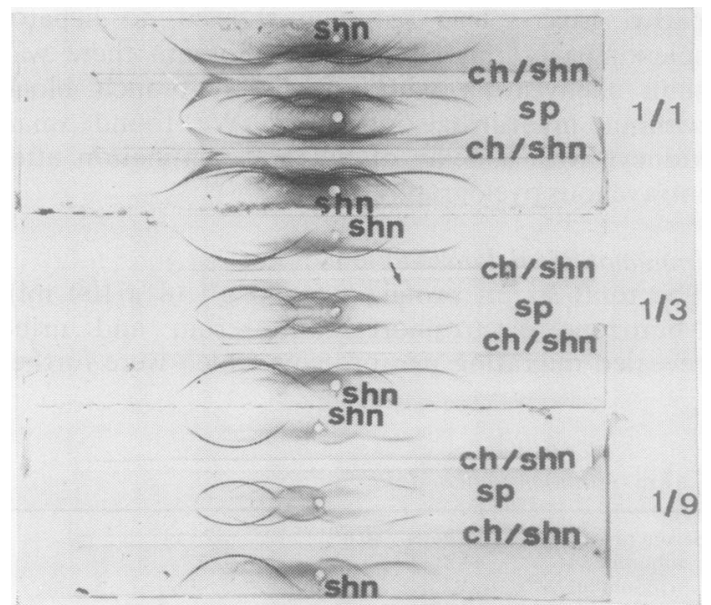

Fig. 2 Immunoelectrophoresis of the patient's serum (sp) undiluted (1/1), diluted $1 / 3$ and $1 / 9$ in central wells of each slide compared with normal human serum (shn), undiluted (1/1), diluted $1 / 3$ and $1 / 9$ in exterior wells. The slides are developed with a polyspecific antiserum antinormal human serum. 


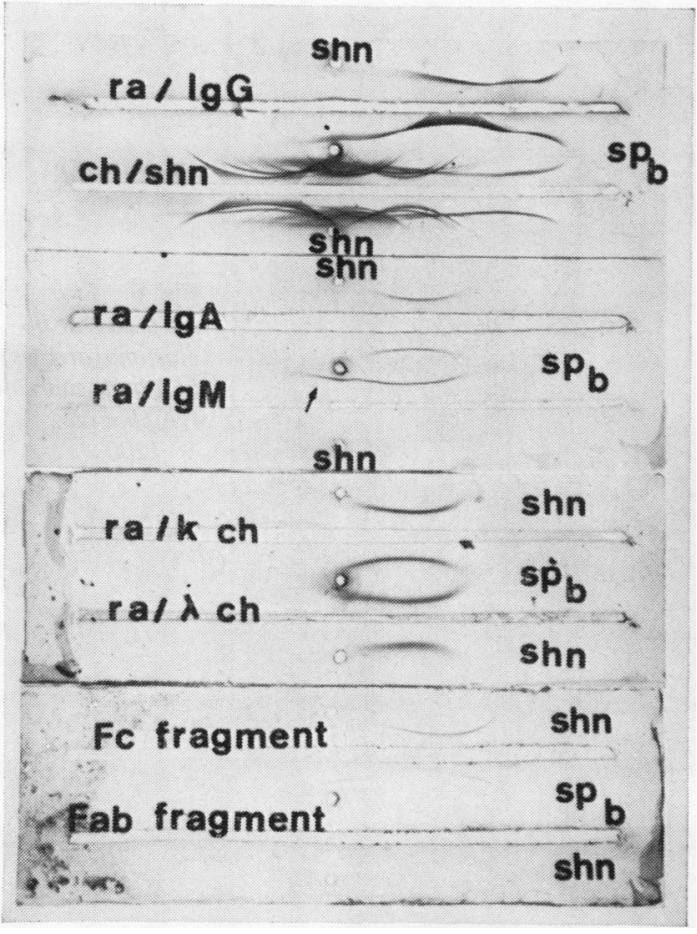

Fig. 3 Immunoslectrophoresis of the patient's serum. $A$ broadly dispersed precipitation arc is demonstrated in the serum developed with anti-IgG antiserum ( $\mathrm{ra} / \mathrm{IgG})$ and anti-Fc fragment antiserum. This arc is not developed with anti-Fab antiserum nor with ant $i-K$ and anti- $\lambda$ antisera $(\mathrm{ra} / \mathrm{K} \mathrm{ch} ; \mathrm{ra} / \lambda \mathrm{ch})$.

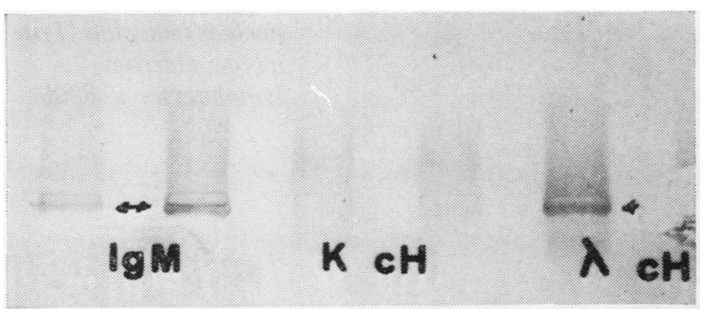

Fig. 4 Immunofixation analysis of the patient's serum. $A$ fine reacting band with the anti-Ig $M$ antiserum and the $\lambda$ light chain antiserum is clearly identified. The absence of the $K$ band is strongly suggestive of a IgM $\lambda$ monoclonal component.

conjugated antisera was positive in many lymphocytes. Fc fragment antiserum gave a marked intracytoplasmic fluorescence in a few plasma cells. Several lymphocytes appeared with intranuclear inclusions limited by a single membrane contrasting with the two-layer membrane of the nuclear blebs.

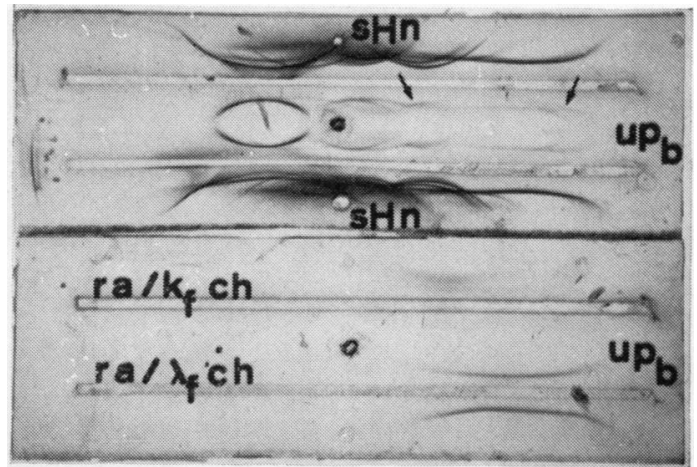

Fig. 5 Immunoelectrophoresis pattern of the $\times 100$ concentrated patient's urine (up) in the central wells; normal human serum in exterior wells (sHn). The top slide is developed with anti-normal human serum and reveals two abnormal components. The first is the Fc fragment as correlated by agarose gel electrophoresis and the second $a$ Bence-Jones $\lambda$ light chain reacting with ant $i-\lambda$ antiserum ( $\left.\mathrm{ra} / \lambda_{f} \mathrm{ch}\right)$.

Sometimes a nuclear body with ribosome-like structures was seen near these inclusions (Figs 6-8).

Nucleoli were often observed. Some lymphocytes presented cytoplasmic granules surrounded by a clear zone. Patterns of cytoplasmic microfilaments were also encountered. The plasma cells showed a variable dilatation of rough endoplasmic reticulum (RER) cisternae containing electron-dense proteinaceous material. There was a well-developed Golgi apparatus. A few plasma cells presented the aspect of 'storage cells' with an extreme expansion of the RER cisternae. Clasmatosis with release of cytoplasmic fragments containing RER cisternae was also encountered. A very striking feature was the presence of cytoplasmic vacuoles of variable size inside many plasma cells. These vacuoles frequently contained membrane fragments which appeared to collapse away from their limiting membrane. More often located near the Golgi apparatus, they sometimes seemed to be in continuity with broken cisternae of RER (Figs 9-11). It was not unusual for vacuoles to extend to the periphery of the plasma cell where defects in the plasma membrane occurred.

\section{Discussion}

The main interest of this case is the association of $\gamma 3 \mathrm{HCD}$ and Waldenström's macroglobulinaemia. The laboratory and pathological data, with the exception of serum and urine proteins, were nonspecific. Anaemia and heart failure were the only striking features. 


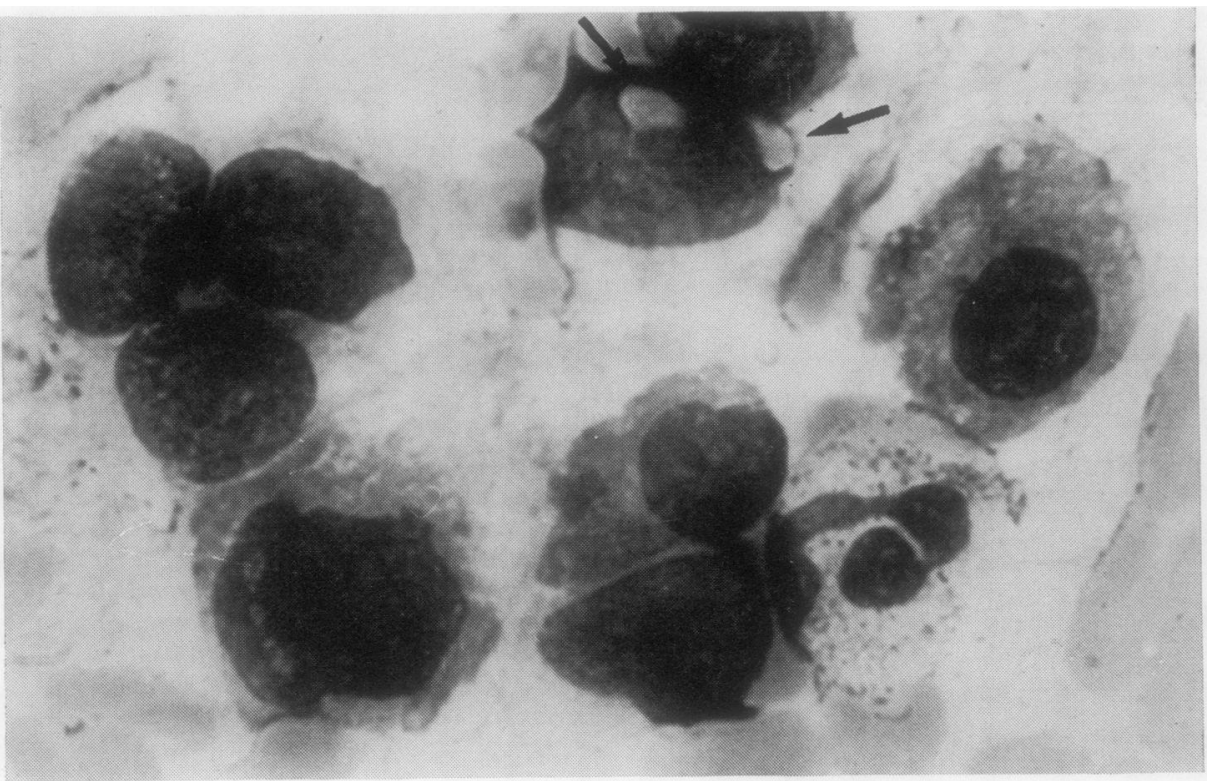

Fig. 6 Two intranuclear inclusions (arrows) in a bone marrow lymphocyte. $\times 1200$

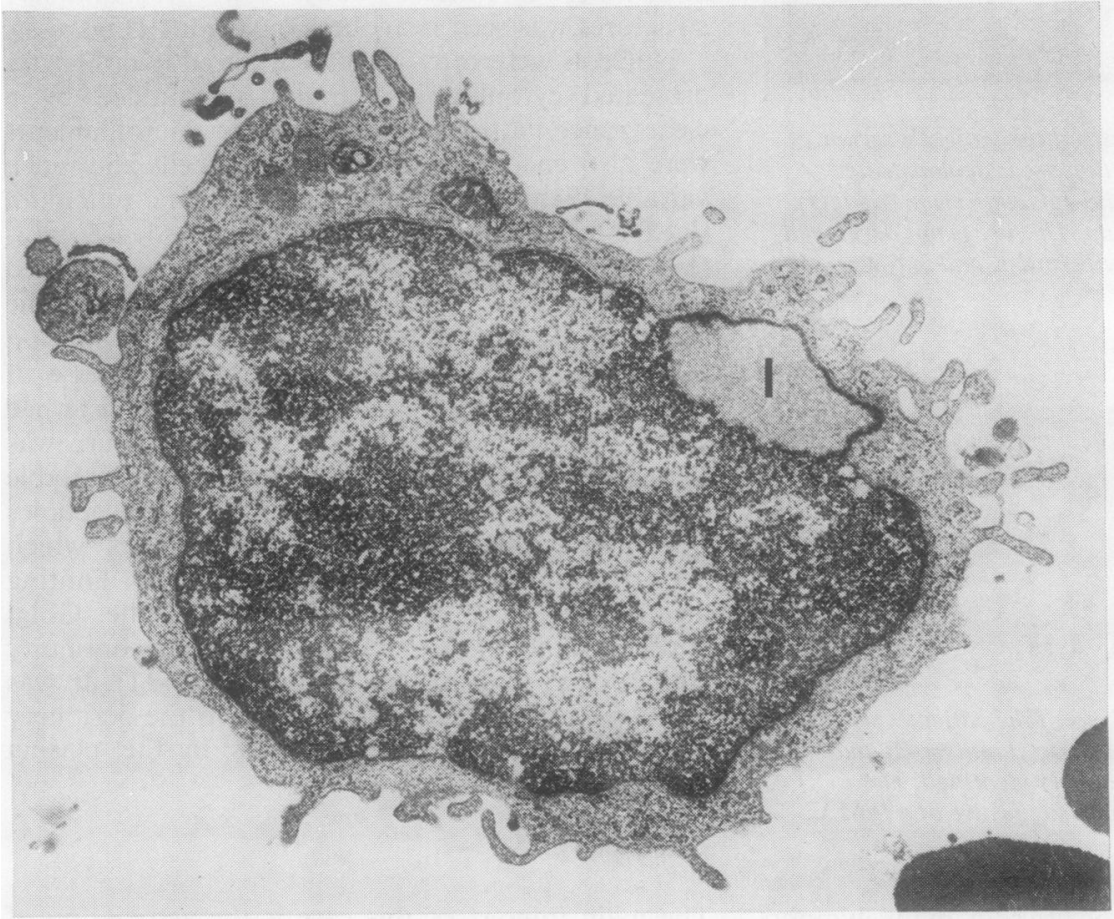

Fig. 7 Similar intranuclear inclusion (I) in abone marrow lymphocyte. $\times 8000$

There was no abrupt change in the clinical condition of the patient as described by Spengler et al. (1972); indeed the initial paraproteins persisted unchanged throughout the period of observation.
Physicochemical data published on $\gamma 3$ HCD explain some of our observations (Fine et al., 1968; Keller et al., 1970; Isobe and Osserman, 1974; Josephson et al., 1975; Virella et al., 1977; Creyssel 


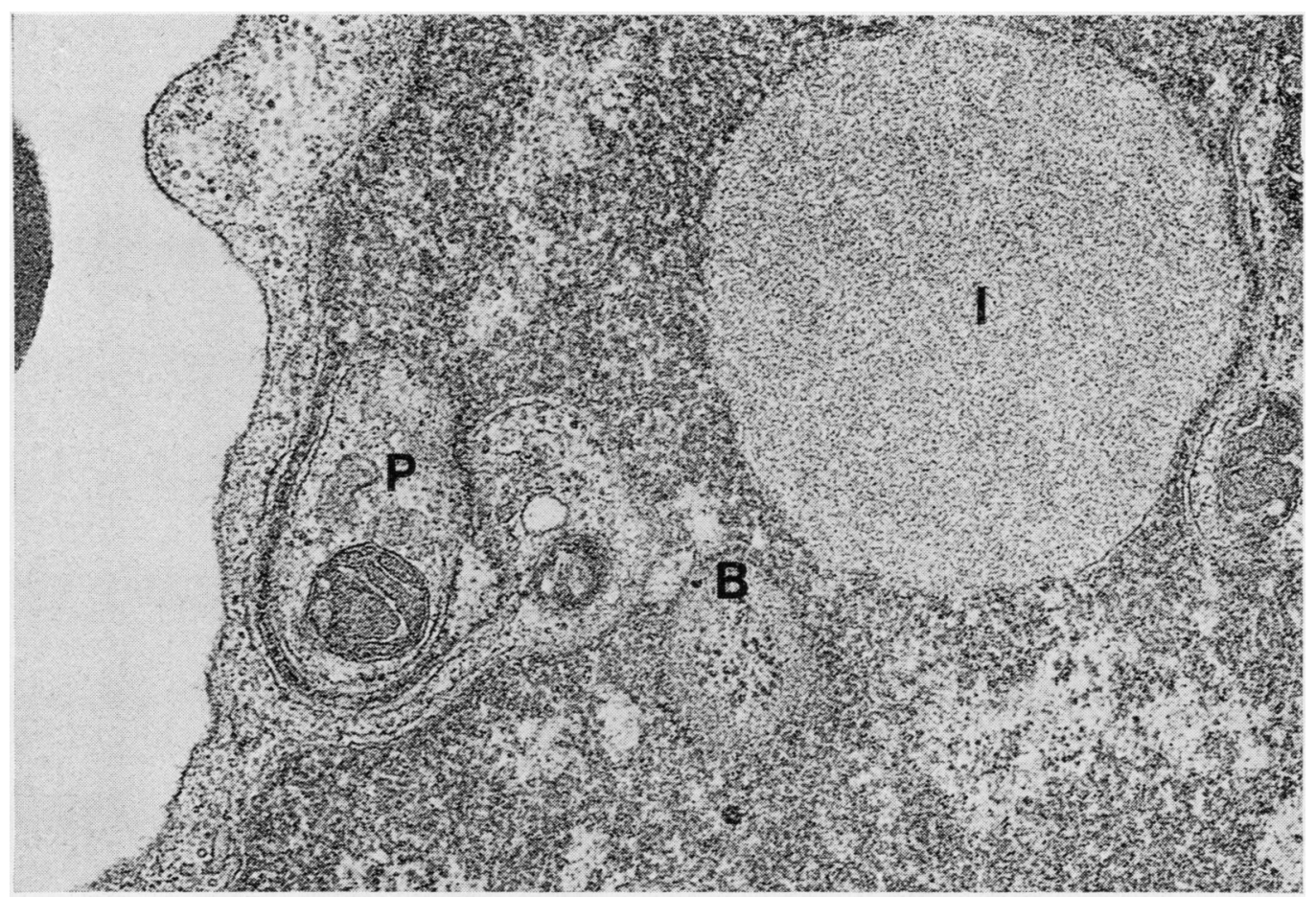

Fig. 8 High magnification of a lymphocyte showing an intranuclear inclusion $(I)$, a nuclear bleb $(P)$, and a nuclear body with ribosome-like material $(B) \times 44000$

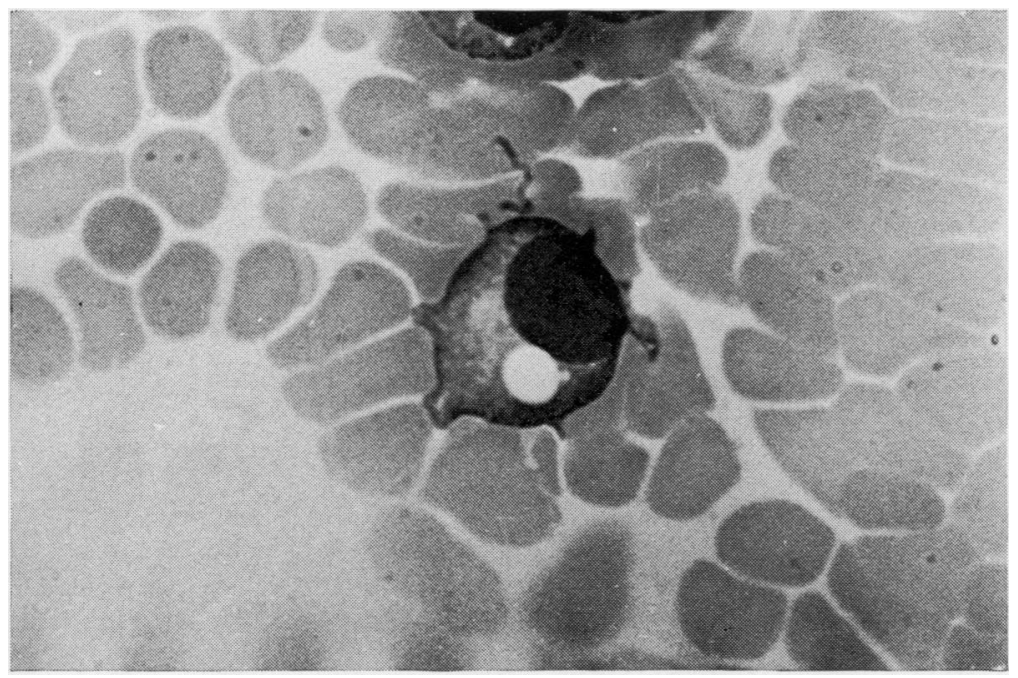

Fig. 9 A vacuolated plasma cell. $\times 1125$

et al., 1977; Adlersberg et al., 1978). The amounts of IgG and IgM were always greater than the value calculated for the fraction of the serum protein on the basis of the total protein concentration and the fractional values obtained from the microzone electrophoresis scan. These findings suggest an IgG fragment diffusing through the gel at a considerably faster rate than normal $7 \mathrm{~S} \mathrm{IgG.}$ 


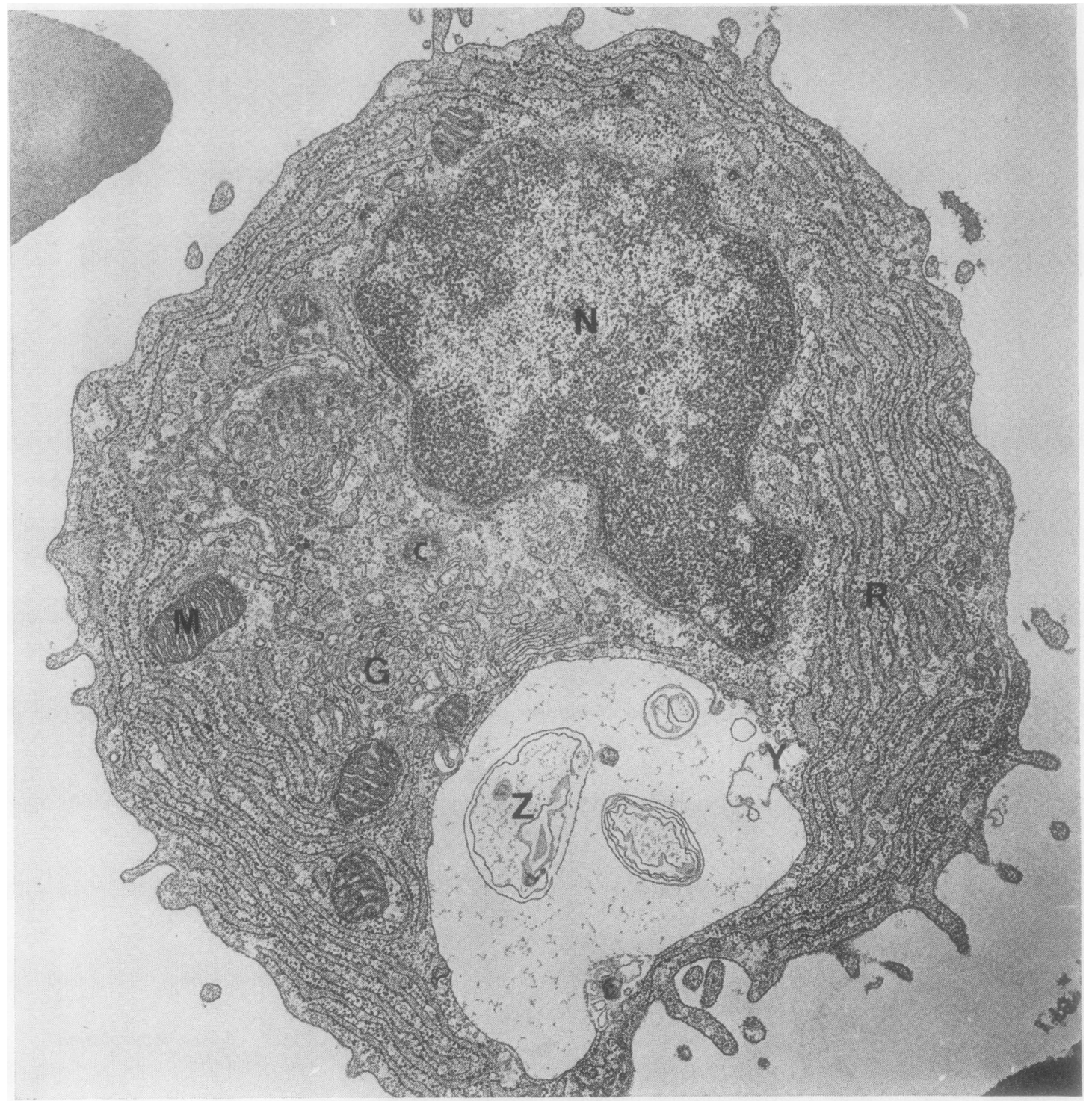

Fig. 10 A plasma cell with a large cytoplasmic vacuole: $N=$ nucleus, $\gamma=$ disrupted membrane, $Z=$ membrane fragments, $c=$ centriole, $G=$ Golgi apparatus, $R=$ rough endoplasmic reticulum, $M=$ mitochondria.$\times 21230$

Definitive diagnosis was based on the demonstration in serum and urine of a broad spike with inter $\beta-\gamma$ mobility, reactive with antisera to heavy chains but not light chains. The immunoelectrophoretic analyses clearly established the presence of the $\mathrm{Fc}$ fragment associated with failure of light chain production. There was no evidence of a spontaneous cleavage of the monoclonal IgG into its constituent $\mathrm{Fc}$ and $\mathrm{Fab}$ fragments.
The results of the immunofixation studies showed the monoclonality of the IgM confirmed by the strong monospecificity of the antiserum; when tested by bidimensional electrophoresis and some experiments performed with purified IgM fraction isolated by preparative polyacrylamide gel electrophoresis, other immunoglobulin classes cannot be detected.

From these observations different questions can 


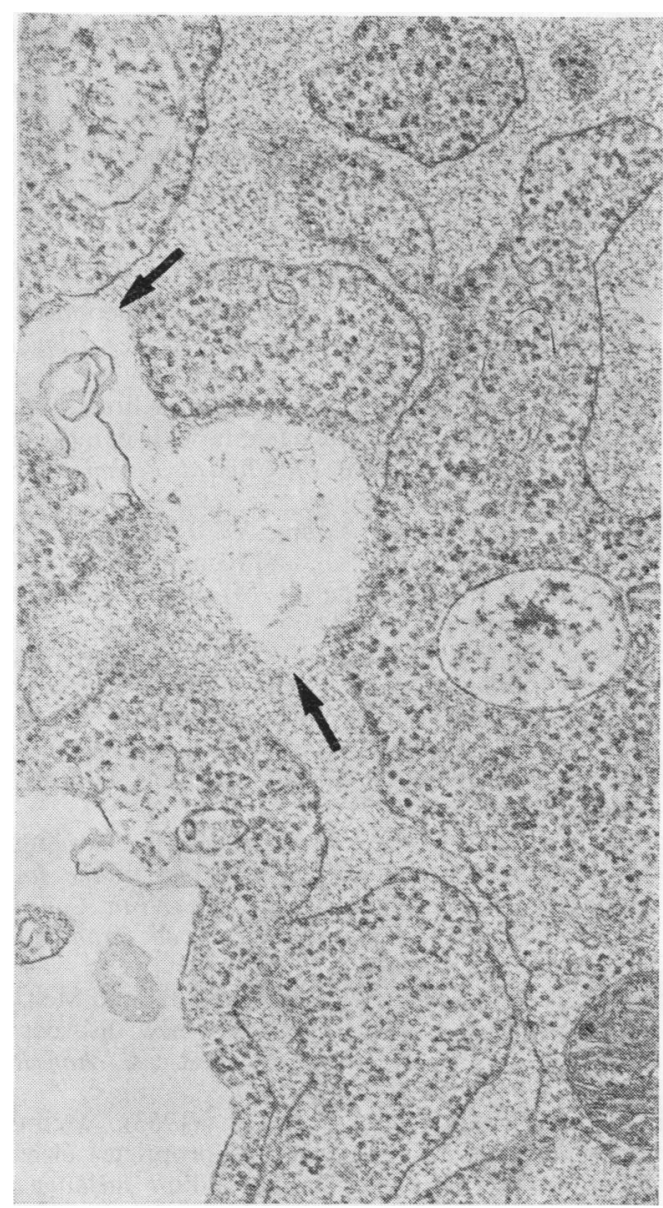

Fig. 11 High magnification shows a communication between RER cisternae and a vacuole (arrows). × 36000

be considered. Are the two paraproteins secreted by one or two cellular clones or by a submutation of the malignant clone previously synthesising IgM or $\gamma 3$ heavy chains, as suggested by Virella et al. (1977)? Further experiments on their chemical structure would be necessary to classify this $\gamma$ HCD protein into one of the groups described by Franklin (1978), in other words, to determine the position of the aminoacid deletion.

A study of the transcription and the translation of DNA is needed to define the mechanism responsible for these deletions. A messenger RNA smaller than that for an intact heavy chain (Buxbaum and Alexander, 1977), the probability that more than one gene may be involved in the regulation of heavy and light chain synthesis, and the existence of regulatory defects in the cell (Franklin, 1978) have been suggested.
In addition to this defect, the presence of other immunoglobulin variants in serum and urine may be ascribed to a plasma cell neoplasm which may or may not be related to the heavy chain disease.

The haematological pattern was characterised by lymphocytosis in the blood and by a slightly increased number of lymphocytes and plasma cells in the bone marrow with many morphological abnormalities. The lymphocytes had nuclear pockets, intranuclear inclusions, nuclear bodies, and several nucleoles. Their cytoplasm was relatively abundant with some RER cisternae and occasionally patterns of microfilaments, as is often seen in neoplastic lymphocytes (Zucker-Franklin, 1975). The nuclear blebs correspond to cytoplasmic invaginations inside the nucleus. The most striking lymphocyte abnormalities were the presence of intranuclear inclusions and a few nuclear bodies. The intranuclear inclusions limited by a monolayer membrane were probably formed by invagination of the inner nuclear envelope. Their origin has not yet been elucidated; some authors attribute to them a cytoplasmic, others a nuclear, origin (Bessis et al., 1963; Brittin et al., 1963; Kuhn, 1967). Such inclusions are characteristic of Waldenström's disease. They can be seen in myeloma cells and also in plasma cells in inflammatory conditions. Immunofluorescent techniques have revealed the presence of IgM inside similar inclusions (Solomon et al., 1963). The nuclear bodies and their ribosome-like particles were described near intranuclear inclusions in cases of macroglobulinaemia by Kuhn (1967); his work supports the intranuclear origin of these inclusions.

Spectacular morphological changes were also detected in the plasma cell line. Plasmacytes showed all intermediate stages of immunoglobulin accumulation. 'Flaming cells' and 'storage cells' represented the extreme degree of this accumulation (Fisher and Zawadzki, 1970; Maldonado et al., 1965). The clasmatosis phenomenon, as in the myeloma cells, indicated secretion of pathological immunoglobulins (Maldonado et al., 1965). But the most unusual feature for $\gamma \mathrm{HCD}$ was the presence of cytoplasmic vacuoles of different sizes. This appearance is characteristic of $\mu$ HCD (Ballard et al., 1970; Forte et al., 1970; Franklin, 1975; Jonsson et al., 1976), except for the observation of several cytoplasmic vacuoles on light microscopy in the first case of $\gamma$ HCD (Franklin et al., 1964). Similar vacuoles were also reported by Aula et al. (1975) inside lymphocytes in lipidic lysosomal disorders. The ultrastructural analysis of vacuolated plasmacytes agrees with the descriptions of Zucker-Franklin in a case of $\mu$ HCD (Zucker-Franklin and Franklin, 1971). The vacuoles were indeed limited by a wavy disrupted membrane and contained membrane fragments. As Zucker- 
Franklin has noted, the vacuoles are not due to dilatation of RER, but at high magnification a continuity between the vacuoles and RER cisternae may be observed.

In conclusion, unusual findings encountered in this case are, on the one hand, the association of three abnormal proteins and, on the other, the presence of vacuolated plasma cells typical of $\mu \mathrm{HCD}$.

This work was supported by contract No. 3900175 of the Fonds de la Recherche Scientifique Médicale.

We are grateful to Professor P. Dustin, Professor A. Govaerts, Dr R. Denolin-Reubens, and Dr P. Nève for suggestions and criticism of the manuscript.

We thank Mrs R. Menu, Mrs J. Gerard, Mrs I. Sprangers, Mr J. Hupin, and Mr J. M. Famelard for technical assistance and $\mathrm{Mr} \mathbf{J}$. L. Conreur and Mr R. Vienne for photographic work.

\section{References}

Adlersberg, J. B., Grann, V., Zucker-Franklin, D., Frangione, B., and Franklin, E. C. (1978). An unusual case of a plasma cell neoplasm with an IgG3 $\lambda$ myeloma and a $\gamma 3$ heavy chain disease protein. Blood, 51, 85-96.

Andrews, P. (1965). The gel-filtration behavior of proteins related to their molecular weights over a wide range. Biochemical Journal, 96, 595-606.

Aula, P., Rapola, J., and Anderson, L. C. (1975). Distribution of cytoplasmic vacuoles in blood $\mathrm{T}$ and $\mathrm{B}$ lymphocytes in two lysosomal disorders. Virchows Archiv B Cell Pathology, 18, 263-271.

Ballard, H. S., Hamilton, L. M., Marcus, A. J., and Illes, C. H. (1970). A new variant of heavy chain disease ( $\mu$-chain disease). New England Journal of Medicine, 282, 1060-1062.

Bessis, M., Breton-Gorius, J., and Binet, J. L. (1963). Étude comparée du plasmacytome et du syndrome de Waldenström: examen au microscope éléctronique. Nouvelle Revue Française d'Hématologie, 3, 159-184.

Bloch, K. J., Lee, L., Mills, J. A., and Haber, E. (1973). Gamma heavy chain disease: an expanding clinical and laboratory spectrum. American Journal of Medicine, $55,61-70$.

Brittin, G. M., Tanaka, Y., and Brecher, G. (1963). Intranuclear inclusions in multiple myeloma and macroglobulinemia. Blood, 21, 335-351.

Buxbaum, J. N., and Alexander, A. (1977). Heavy chain disease in man: partial purification and translation of the mRNA coding for the deleted protein (Abstract). Clinical Research, 25, 334A.

Creyssel, R., Brizard, C. P., Gibaud, A., Cordier, J. F., and Gibaud, H. (1977). Maladie des chaînes lourdes gamma d'apparition sécondaire au cours de l'évolution d'une macroglobulinémie. Lyon Médical, 237, 215-220.

Delmas-Marsalet, Y., Voisin, D., Hennache, G., Bauters, F., and Goudemand, M. (1971). Étude clinique et biologique de la maladie des chaînes lourdes gamma: à propos d'une nouvelle observation. Nouvelle Revue Française d'Hématologie, 11, 717-734.

Feremans, W. W., Neve, P., and Caudron, M. (1978). IgM lambda cytoplasmic crystals in three cases of immunocytoma: a clinical, cytochemical, and ultrastructural study. Journal of Clinical Pathology, 31, 250-258.

Fine, J. M., Zakin, M. M., Faure, A., and Boffa, G. A. (1968). Myélome avec paraprotéine sérique $\gamma \mathrm{G}$ et élimination urinaire d'un fragment de $\gamma \mathrm{G}$ dépourvu de chaînes légères. Revue Française d'Études Cliniques et Biologiques, 13, 175-178.

Fisher, E. R., and Zawadzki, Z. A. (1970). Ultrastructural features of plasma cells in patients with paraproteinemias. American Journal of Clinical Pathology, 54, 779-789.

Forte, F. A., Prelli, F., Yount, W. J., Jerry, L M., Kochwa, S., Franklin, E. C., and Kunkel, H. G. (1970). Heavy chain disease of the $\mu(\gamma \mathrm{M})$ type: report of the first case. Blood, 36, 137-144.

Frangione, B., and Franklin, E. C. (1973). Heavy chain diseases: clinical features and molecular significance of the disordered immunoglobulin structure. Seminars in Hematology, 10, 53-64.

Franklin, E. C. (1975). $\mu$-chain disease. Archives of Internal Medicine, 135, 71-72.

Franklin, E. C. (1978). Immunoglobulin variantsheavy chain diseases. XVIIth Congress of the International Society of Hematology and XVth Congress of the International Society of Blood Transfusion, Plenary Session, pp. 105-109. Paris.

Franklin, E. C., Lowenstein, J., Bigelow, B., and Meltzer, M. (1964). Heavy chain disease. A new disorder of serum $\gamma$-globulins. Report of the first case. American Journal of Medicine, 37, 332-350.

Grabar, P., and Williams, C. A. (1953). Méthode permettant l'étude conjuguée des propriétés électrophorétiques et immunochimiques d'un mélange de protéines: application au sérum sanguin. Biochimica Biophysica Acta, 10, 193-194.

Hobbs, J. R. (1971). Immunocytoma o'mice an'men. British Medical Journal, 2, 67-77.

Isobe, T., and Osserman, E. F. (1974). Plasma cell dyscrasia associated with the production of incomplete (? deleted) IgG $\lambda$ molecules, gamma heavy chains, and free lambda chains containing carbohydrate. Description of the first case. Blood, 43, 505-526.

Johansson, B. G. (1972). Agarose gel electrophoresis. Scandinavian Journal of Clincal Laboratory Investigation, 29, (Supplement) 124, 7-19.

Jønsson, V., Videbaek, A., Axelsen, N. H., and Harboe, M. (1976). $\mu$-chain disease in a case of chronic lymphocytic leukaemia and malignant histiocytoma. 1. Clinical aspects. Scandinavian Journal of Hematology, 16, 209-217.

Josephson, A. S., Nicastri, A., Price, E., and Biro, L. (1975). $\mathrm{H} \mu$ chain fragment and monoclonal IgA in a lymphoproliferative disorder. American Journal of Medicine, 54, 127-135.

Keller, H., Spengler, G. A., Skvařil, F., Flury, W., Noseda, G., and Riva, G. (1970). Zur Frage der Heavy chain disease: ein Fall von IgG-heavy-chain-Fragment 
und IgM-Typ K-Paraproteinämie mit Plasmazellen leukämie. Schweizerische medizinishe Wochenschrift, 100, 1012-1022.

Kuhn, C. (1967). Nuclear bodies and intranuclear globulin inclusions in Waldenström's macroglobulinemia. Laboratory Investigation, 17, 404-415.

Lennert, K., Mohri, N., Stein, H., and Kaiserling, E. (1975). The histopathology of malignant lymphoma, British Journal of Haematology, 31, Supplement, 193203.

Luft, J. H. (1961). Improvements in epoxy resin embedding methods. Journal of Biophysical and Biochemical Cytology, 9, 409-414.

Mancini, G., Carbonara, A. O., and Heremans, J. F. (1965). Immunochemical quantitation of antigens by single radial immunodiffusion. Immunochemistry, 2 , 235-254.

Millonig, G. (1962). Further observations on a phosphate buffer for osmium solutions in fixation. In Proceedings of the 5th International Congress for Electron Microscopy, edited by S. S. Breese, Jr, p.8. Academic Press, New York.

Maldonado, J. E., Bayrd, E. D., and Brown, A. L. Jr. (1965). The flaming cell in multiple myeloma: a light and electron microscopy study. American Journal of Clinical Pathology, 44, 605-612.

Osserman, E. F., and Lawlor, D. (1961). Immunoelectrophoretic characterization of the serum and urinary proteins in plasma cells myeloma and Waldenström's macroglobulinemia. Annals of the New York Academy of Sciences, 94, 93-109.

Osserman, E. F., and Takatsuki, K. (1964). Clinical and immunochemical studies of four cases of heavy $\left(\mathrm{H}_{\gamma 2}\right)$ chain disease. American Journal of Medicine, 37, 351373.

Pearse, A. G. E. (1960). Fluorescent antibody methods. In Histochemistry, Theoretical and Applied, 2nd edition, p. 137. Churchill, London.
Ritchie, R. F., and Smith, R. (1976). Immunofixation. III. Application to the study of monoclonal proteins. Clinical Chemistry, 22, 1982-1985.

Seligmann, M. (1972). Heavy chain diseases. Revue Européenne Etudes Cliniques et Biologiques, 17, 349-355.

Solomon, A., Fahey, J. L., and Malmgren, R. A. (1963). Immunohistologic localization of gamma 1-macroglobulins, beta $2 \mathrm{~A}$ myeloma proteins, 6.6S gammamyeloma proteins and Bence-Jones proteins. Blood, 21, 403-423.

Spengler, G. A., Steinberg, A. G., and Skvaril, F. (1972). Development of a second monoclonal immunoglobulin $G$ in a patient with late manifestation of myeloma. Acta Medica Scandinavica, 192, 309-314.

Virella, G., Monteiro, J. M. N., Lopes-Virella, M. F., Soares, A. D., and Fudenberg, H. H. (1977). A synchronous development of two monoclonal proteins (IgM $\lambda$ and $\gamma 1$ chains) in a patient with abdominal lymphoma. Cancer, 39, 2247-2253.

Weber, K., and Osborn, M. (1969). The reliability of molecular weight determinations by dodecyl sulfatepolyacrylamide gel electrophoresis. Journal of Biological Chemistry, 244, 4406-4412.

Zucker-Franklin, D. (1964). Structural features of cells associated with the paraproteinemias. Seminars in Haematology, 1, 165-198.

Zucker-Franklin, D. (1975). Cellular structure and function in normal and neoplastic lymphoid cells. Archives of Internal Medicine, 135, 55-60.

Zucker-Franklin, D., and Franklin, E. C. (1971). Ultrastructural and immunofluorescence studies of the cells associated with $\mu$-chain disease. Blood, 37, 257-271.

Requests for reprints to: Dr C. J. Bieva, St Pierre Hospital (Transfusion), rue Haute 322, B-1000 Brussels, Belgium 